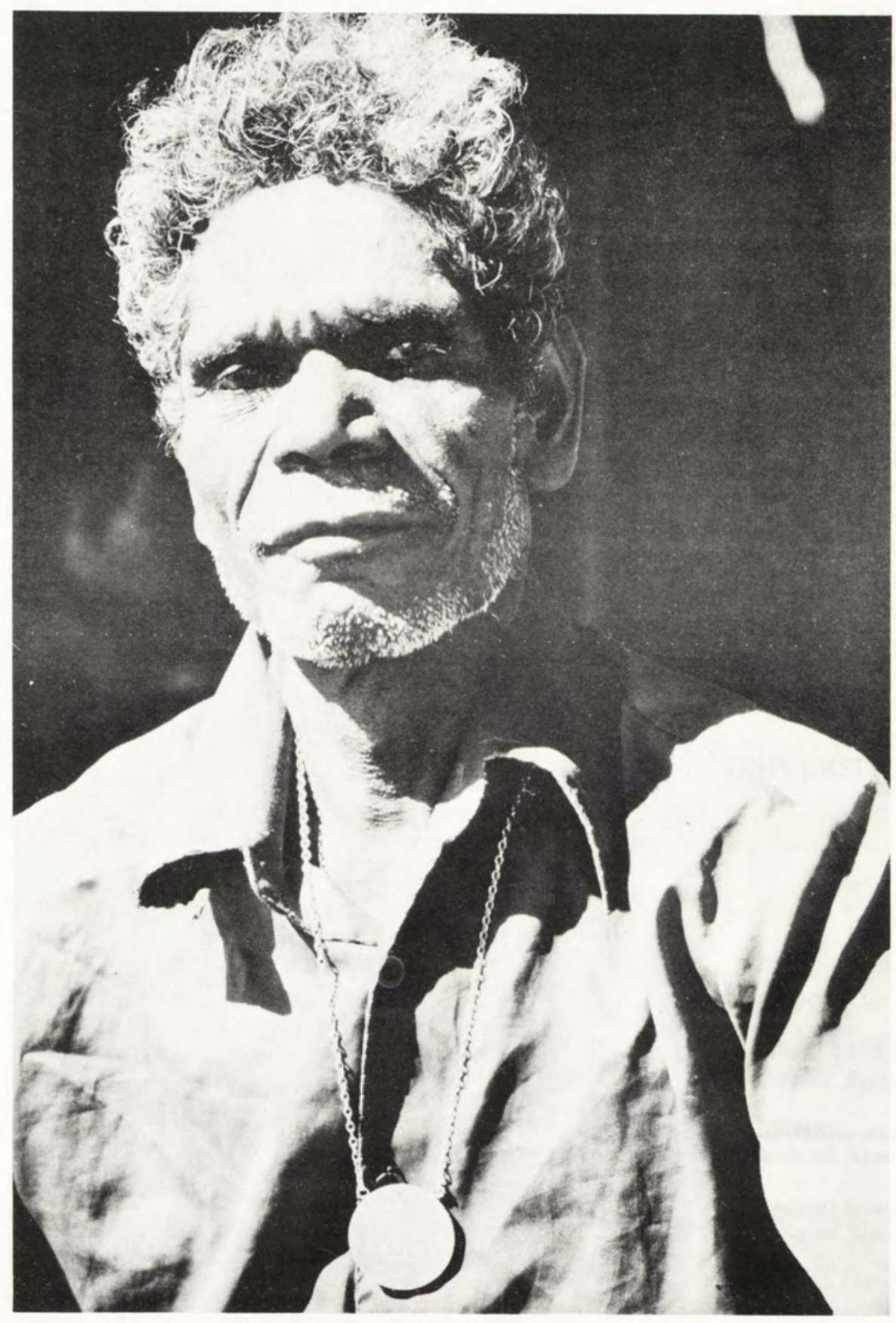

Malangi, wearing the medallion commemorating his contribution to the design of the Australian \$1 note.

Photograph by Penny Tweedie, 1979. 


\title{
MALANGI: THE MAN WHO WAS FORGOTTEN BEFORE HE WAS REMEMBERED
}

\author{
David H. Bennett
}

On 14 February 1966, 'C-Day', Australia introduced decimal currency. Four new dollar bank notes $(\$ 1, \$ 2, \$ 10, \$ 20)$ designed by Gordon Andrews were released. The one dollar note was described in various sources, official and unofficial, as featuring

on the front a portrait of Her Majesty, Queen Elizabeth II in the

regalia of the Order of the Garter and a new exemplification of the coat-of-arms of the Commonwealth of Australia. On the back is a line interpretation of an Aboriginal bark painting and of Aboriginal rock paintings and carvings. 1

The design of the back of the note consists of three distinct sections, as shown below. The stick-like hunters in the upper right hand section (known as mimi figures) were described in the official release as 'cave paintings from western Arnhem Land of the Nalbidji people - more or less kindly spirit people who live in the rocks of the western Arnhem Land plateau'. 2 The kangaroo, goanna and snake in the lower centre section are representations of X-ray art, also derived from the rock art of western Arnhem Land. The tree and everything to the left of it was redrawn from a bark painting from eastern Arnhem Land.

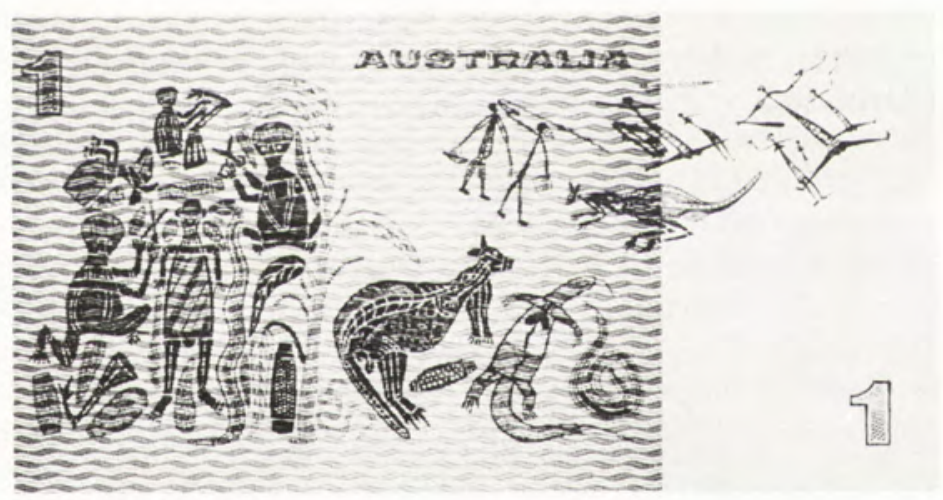

Design of back of the Australian $\$ 1$ note, by permission of the Reserve Bank. Photograph by Colin Roach.

1 Official Yearbook of Australia 1966:678; see also Anon. 1966:215, Andrews 1966: 292.

2 Pullen 1966. 
Combining bark painting and rock art is like making a composite grouping of works by Velasquez, Goya, and Dali simply because they are all Spanish artists. The result appears reasonably harmonious but this is due to the indifference of the Western eye. Nevertheless some differences are readily observable; the mimi figures are stick-like while the figures from the bark painting are more solid. The X-ray snake exhibits vertebrae while the bark painting snake is filled with circles. The other figures show similar stylistic variation. The layman is not made aware of the difference in period of the design sources. The examples of rock art are of unknown antiquity and were discovered by C.P. Mountford in 1948.3 A contemporary Aboriginal artist living near Milingimbi, Malangi (sometimes called 'Dollar George') created the bark painting, but the original artist's identity was forgotten for three years.

I learned the circumstances leading to the selection of Malangi's painting for the dollar note as a circuitous and confused story. The first version I heard was that an Arnhem Land bark painting in a French collection was seen by an Australian Prime Minister who urged its selection as a design for the new decimal currency.

The story began in 1963. Karel Kupka, a Hungarian art collector and anthropologist living in France, had met Malangi 'through the kindly teachers of the Milingimbi Methodist Mission and ... was struck with the astonishing personal style of his work'. 4 Kupka, who had made several previous collecting trips to Arnhem Land, took Malangi's painting 'The Hunter' 5 back to Paris. There he gave several paintings, including Malangi's, to the collection of the Paris Museum of Arts of Africa and Oceania for which he worked. He also secured finance from Qantas to stage an exhibition of art from Arnhem Land. By the time I made inquiries, a belief had grown up that either Harold Holt or William McMahon or both saw this exhibition and were so impressed by Malangi's work that they recommended its use on the new notes. This story is apocryphal. The painting's odyssey did begin with Karel Kupka and this explains why Malangi's painting is now in Paris. The history of its selection, related to me by people acquainted with Malangi and with the story of the design, is strange, but it did not involve a Prime Minister. 6

In April 1963, the same year Kupka discovered Malangi's painting, the Australian Government decided to convert to decimal currency and

3 Pullen 1966.

4 Pullen 1966.

5 Helen Groger-Wurm, personal communication 23 March 1979; Allen 1975.

6 Information was generously provided, in letters and conversation, by Lance Bennett, 7 May 1979; H.C. Coombs, 1 March 1979; Alan Fidock, 18 May 1979; K.F. Thompson, 17 May 1979; Penny Tweedie, October 1979; John von Sturmer, 23 March 1979. 
asked seven designers to submit suggestions and preliminary sketches. Among the guidelines for the artists was 'a suggestion that one note might embody an Aboriginal theme'. Kupka, on his collecting trip at this time, met A.C. McPherson, Secretary of the Reserve Bank of Australia, and gave him photographs of several bark paintings he had just collected. Among them was Malangi's painting. McPherson passed these photographs on to the seven designers. Gordon Andrews, whose designs were ultimately selected, incorporated Malangi's basic pattern. ${ }^{7}$

Between April 1963 and February 1966 the identity of the artist whose bark painting was used was forgotten. Malangi received no recognition or compensation for his contribution. Without the intervention of the journalist Roland Pullen and the mission teacher Alan Fidock he might forever have been unrecognized and uncompensated. Pullen first brought the oversight to public attention on 2 February 1966 in an article in the Adelaide Advertiser. Twelve days later the new dollar notes were seen by Fidock in Arnhem Land.8

Alan Fidock, one of the teachers at the Milingimbi Mission who had introduced Karel Kupka to Malangi, recognized part of the design as depicting the Gurrumurringu myth which he knew to be the 'property' of Malangi. Fidock asked Malangi if he had agreed to the use of the design or the myth for the new money and discovered that he had not. Through the mission administration Fidock wrote to H.C. Coombs, then Governor of the Reserve Bank, suggesting that a suit might be brought on Malangi's behalf for breach of copyright. Coombs investigated the matter and found that indeed Malangi had received neither recognition nor reward. The portrait of the Queen was attributed to the artist Douglas Glass, but credit for the rest of the design had been given to Andrews, whose initials appear in the design at the lefthand side of the tree base. The designers were responsible for negotiating rights to sources included in their designs. Coombs could offer only one explanation for this oversight: he and other bank officers, and presumably Gordon Andrews, had assumed 'that the designs were the work of some traditional Aboriginal artist long dead'.9

Coombs 'gave instructions that Malangi was to be found and arrangements made for him to receive both a fee and some symbolic acknowledgement of his contribution to the design of the notes. After consultation with Malangi he was given .... (a) medallion, a fishing kit and .... (a) fee . . '10 The fee was a thousand dollars, with which Malangi bought an aluminium dinghy and outboard motor. The fishing kit consisted of a tackle box complete with tackle and lures. The

7 H.C. Coombs, personal communication 1979.

8 Pullen 1966; Thompson, personal communication 1979.

9 Coombs, personal communication 1979.

10 Coombs, personal communication 1979. 
medallion, of which Malangi is most proud, is a brushed silver disk approximately five centimetres in diameter, suspended on a silver chain. On the front of the medallion is the inscription:11

\author{
Presented to \\ Malangi \\ By Dr H.C. Coombs \\ Governor \\ Reserve Bank of Australia \\ 7th August 1967
}

On the back is inscribed:

\title{
To Commemorate \\ His contribution to the design of the \\ Australian $\$ 1$ note
}

Malangi's contribution to the dollar note depicts in part the mourning rites which are still performed at the death of a member of his clan, the Manharrngu. 12 It tells the story of the ancestral hero Gurrumurringu, the great hunter. Gurrumurringu (the central figure) when hunting one day speared a wallaby (segmented, at top and bottom) and found yams and fruits (ovoid shapes around human figures). He was returning with these to his wife, Durandur (not pictured) when he stopped beside a waterhole beloved and protected by her, to rest and butcher the wallaby. At the waterhole lived an evil tree spirit. The tree depicted - a real tree which still stands beside the waterhole - is sometimes called a milk tree. The tree spirit sent out the brown snake which lived with him, to bite Gurrumurringu. As Gurrumurringu cooked a haunch of wallaby (top centre), he felt the sharp pain of the snake's bite and died. When he was found his clansmen (two figures flanking central figure) laid out his body and prepared it for burial (the crosshatching represents the painting of his body). They sang of his exploits and his death, and played the clapsticks over his body. Later his bones were transferred to a burial log (perhaps represented by the dark cylinder at base of tree). ${ }^{13}$

11 Tweedie, personal communication 1979.

12 There seems to be some difference of opinion about Malangi's clan identification: Fidock (n.d.) and Douglas and Oldmeadow (1968) give the name Manharrngu, and I have opted for this in deference to Fidock's place in the story. Tweedie (1979) says Liyagalawumirri, and Allen (1975) says Urgiganjdjar.

13 I have here summarised Malangi's tale of Gurrumurringu from slightly varying versions recorded by Fidock (n.d.), Allen (1975), and Douglas and Oldmeadow (1968). 
Problems still remain concerning the design. Who holds the copyright? Which copyright? The copyright for the painting or the design on the note? The Reserve Bank, the Paris museum, Kupka, Malangi, the Treasury and Gordon Andrews have all been suggested. It appears that the museum owns the painting, Malangi owns the original design, and the Reserve Bank has copyright over the design on the note.14

And what of the other two-thirds of the design, particularly the kangaroo (between the mimi figures and the X-ray art) that no one has ever mentioned? Was it a discovery of Mountford's or a creation of Andrews's? Whatever the story, it - like Malangi - was apparently forgotten.

\section{AUSTRALIAN INSTITUTE OF ABORIGINAL STUDIES}

\section{BIBLIOGRAPHY}

Allen, Louis A. Time before morning: art and myth of the Australian Aborigine. New York, 1975.

Andrews, Gordon. 'Some thoughts on the new Australian bank notes by the designer', Art and Australia, 3, 1966:292-297.

Anon. 'Australia's new decimal currency bank notes', Coins and Medals, 3, 1966: 215.

Australia. Commonwealth Bureau of Census and Statistics. Official Yearbook of Australia, 52, 1966:671-680.

Douglas, Malcolm and David Oldmeadow. Across the top. Melbourne, 1968.

Fidock, Alan. 'Bark painting' in Fidock, Alan and Donald Williams eds. The Aboriginal Australian in north eastern Arnhem Land. (MS., n.d.).

Pullen, Roland. 'Dollar bill design: new note's original design in Paris', Adelaide Advertiser, 5 February 1966:2.

Tweedie, Penny. 'Art of the Aboriginal', Panorama, $21(4), 1979: 4$.

14 Copyright law is a complex subject, and it is only in recent years that authorities have begun to consider the rights of 'tribal' artists. An Australian Institute of Aboriginal Studies committee is currently examining this issue. 